\title{
Pollution from Small and Medium Size Enterprises: Less Understood and Neglected Sources in Nigerian Environment
}

\section{Sridhar MKC ${ }^{1}$, Coker $\mathrm{AO}^{2 *}$ and Achi $\mathrm{C}^{2}$}

${ }^{1}$ Department of Environmental Health Sciences, Faculty of Public Health, University of Ibadan, Ibadan, Nigeria ${ }^{2}$ Department of Civil Engineering, Faculty of Technology, University of Ibadan, Ibadan, Nigeria

\begin{abstract}
Small and Medium Size Enterprises (SMEs) are encouraged by Nigerian Government to develop and sustain the economy and promote employment. They range from process industries, fabrication workshops, service centres, food and drink premises, and several others. A majority of these sprawled up in urban areas though they are also seen in peripheral and rural areas. These centres play significant role in the national economy. At the same time, they also produce a variety of end products and byproducts in solid, liquid or gaseous forms which affect the environment negatively by polluting air, water and soil. This has resulted in eutrophication of water bodies, contamination of groundwater, soil and affected quality of life in the cities. There are well laid out pollution control regulations and guidelines in the country. The Federal Ministry of Environment, The National Environmental Standards and Regulations Enforcement Agency (NESREA) with five Zonal offices implement these regulations. But in spite of these, SMEs sector which is mostly private driven escapes from being questioned on their poor environmental upkeep and disposal of untreated waste products. This paper has drawn examples from selected major urban areas in Nigeria and highlights some of the issues, challenges and possible mitigation measures to safeguard the fragile Nigerian environment.
\end{abstract}

Keywords: SMEs; Pollution control; Nigerian environment; Wastewater treatment; Urban pollution; Quality of life

\section{Introduction}

Ever since the industrial revolution of 1798 in the Great Britain, the trends of managing business industries and economic activities among various countries have not been the same. Urban pollution in Nigeria is well documented. Nigeria has a total land area of 983,213 square $\mathrm{km}$ with a population of over 181 million. The population density is about 120 persons per square $\mathrm{km}$. Industrial activities, in its modern forms, are relatively recent in the history of Nigeria's economic development. During the pre-colonial period, Nigeria featured considerable craft industry as modern factory activity was then not known. After the World War II, Nigeria's economy was mostly from export of raw materials to Europe. Industrial development took on the assembly-type pattern of import substitution until and after the independence. Oil boom of 1970s boosted industrial activities. With financial resources available from oil, and with no development policy, unguided urbanization and industrialization took place. The result was the indiscriminate siting of industries, deforestation and desertification, disregarding the need for environmental concern. The process technologies of some of these industries often resulted in unacceptable levels of toxic and dangerous industrial wastes and effluent emissions. These culminated in the degradation of the environment and devastating ecological and human disasters. At this time, however, the environmental focus has been on major manufacturing process industries and municipal wastes. The Small and Medium size industries were never considered as a threat to the environment. Easily observable and perhaps very scaring are the general human and environmental poverty, the declining quality of life and the underutilized as well as the untapped wealth of human resources. Housing and associated facilities (such as water, electricity, waste disposal) are grossly inadequate. Millions live in substandard environments such as slums, plagued by squalor and grossly inadequate social amenities-- shortage of schools, poor health facilities and lack of opportunities for recreation among [1].

\section{Small and Medium Size Enterprises}

There is no single, clear and widely accepted definition of Small and Medium Size Enterprises (SMEs); rather, definitions vary from country to country (Table 1). These variations depend largely on the size of the economy, types and structure of businesses, and the levels of development. Indicators such as annual turnover (sales) and number of workers are generally used to categorize SMEs. The SMEs nomenclature is used to mean micro, small and medium enterprises and is sometimes referred to as Small and or Less Developed Businesses.

SMEs promote industrial and economic development through the utilization of local raw materials/resources and the production of

\begin{tabular}{|c|c|c|c|}
\hline $\begin{array}{c}\text { Enterprise } \\
\text { size }\end{array}$ & $\begin{array}{c}\text { Number of } \\
\text { employees }\end{array}$ & $\begin{array}{c}\text { Annual turnover in } \\
\text { USD }\end{array}$ & $\begin{array}{c}\text { Gross assets, } \\
\text { excluding fixed } \\
\text { property. in USD }\end{array}$ \\
\hline Medium & $\begin{array}{c}\text { Fewer than } 100 \text { to } \\
200, \text { depending on } \\
\text { industry }\end{array}$ & $\begin{array}{c}\text { Less than } 0.57 \\
\text { million to } 21.4 \text { million, } \\
\text { depending upon } \\
\text { industry }\end{array}$ & $\begin{array}{c}\text { Less than } 0.28 \text { million to } \\
2.57 \text { million, depending } \\
\text { on industry }\end{array}$ \\
\hline Small & Fewer than 50 & $\begin{array}{c}\text { Less than } 0.28 \\
\text { million to } 3.57 \text { million, } \\
\text { depending on industry }\end{array}$ & $\begin{array}{c}\text { Less than } 0.28 \text { million to } \\
0.64 \text { million, depending } \\
\text { on industry }\end{array}$ \\
\hline Very small & $\begin{array}{c}\text { Fewer than } 10 \text { to } \\
20, \text { depending on } \\
\text { industry }\end{array}$ & $\begin{array}{c}\text { Less than } 28,571 \text { to } \\
71,428, \text { depending on } \\
\text { industry. }\end{array}$ & $\begin{array}{c}\text { Less than } 21,428 \text { to } \\
71,428, \text { depending on } \\
\text { industry }\end{array}$ \\
\hline Micro & Fewer than 5 & Less than 21,428 & Less than 14,285 \\
\hline
\end{tabular}

Source: FAO/WHO 2004. Nigeria has adopted that a small scale industry is that which has installed fixed capital below NGN 5 million [24].

Table 1: Definition of SMEs as given in the National Small Business Act (Adapted from South African example) (1 USD=7 South African Rand or Nigerian Naira 360).

*Corresponding author: Coker AO, Department of Civil Engineering, Faculty of Technology, University of Ibadan, Ibadan, Nigeria, Tel: 5456316986; E-mail: cokerwale@gmail.com

Received March 05, 2018; Accepted March 17, 2018; Published March 25, 2018

Citation: Sridhar MKC, Coker AO, Achi C (2018) Pollution from Small and Medium Size Enterprises: Less Understood and Neglected Sources in Nigerian Environment. J Environ Anal Toxicol 8: 558. doi: 10.4172/2161-0525.1000558

Copyright: ( $) 2018$ Sridhar MKC, et al. This is an open-access article distributed under the terms of the Creative Commons Attribution License, which permits unrestricted use, distribution, and reproduction in any medium, provided the original author and source are credited. 
Citation: Sridhar MKC, Coker AO, Achi C (2018) Pollution from Small and Medium Size Enterprises: Less Understood and Neglected Sources in Nigerian Environment. J Environ Anal Toxicol 8: 558. doi: 10.4172/2161-0525.1000558

Page 2 of 7

intermediate goods, through appropriate technologies and traditional practices. They contribute to the economies of many countries globally and provide opportunities for job creation. In countries with food insecure populations, SMEs can assist in maximizing the use of local produce and providing an important source of food. The SME sector is extremely diversified. At one end of the spectrum is the microenterprise sector, or informal sector, which is made up of entities employing one or two persons, including the owner. Small enterprises have a somewhat broader scope and many operate on a more structured basis. Some have established links with medium and large firms as their market for goods and services. Medium-size firms tend to have developed a more outward looking approach to market their products or services, often looking beyond their country's borders to seek new markets. They also may establish linkages with larger firms to create opportunities. In general, however, SMEs cater for the local markets and are normally not involved in international trade. SMEs reduce rural-urban migration and also serve as entrepreneurial training platforms for many youth.

Principal stationary pollution sources include chemical plants, coal-fired power plants, oil refineries, petrochemical plants, nuclear waste disposal activities, incinerators, large livestock farms (dairy cows, pigs, poultry, etc.), polyvinyl chloride (PVC) factories, metals production factories, plastics factories and other heavy industries. Agricultural air pollution comes from contemporary practices, which include clear felling and burning of natural vegetation, as well as spraying of pesticides and herbicides [2]. Most of the SMEs in Nigeria can only survive 5 to 6 years [3]. Several factors contribute to this situation: insufficient capital, irregular power supply, infrastructural inadequacies (water, roads etc.), lack of focus, inadequate market research, over-concentration on one or two markets for finished products, lack of succession plan, inexperience, lack of proper book keeping, lack of proper records or lack of any records at all, inability to separate business and family or personal finances, lack of business strategy, inability to distinguish between revenue and profit, inability to procure the right plant and machinery, inability to engage or employ the right caliber of staff, and cut-throat competition [4].

\section{Nigerian Cities and the SMEs}

Nigeria, a highly populous country in West-Africa has interesting geographical, ecological and environmental profile (Box 1).

Wikipedia has listed 66 larger cities in Nigeria. 14 of these cities were listed as highly populous and WHO listed four cities among them as highly polluted globally [5]. A national survey conducted by the Federal Bureau of Statistics (FBS) across the 36 states of the Federation and the Federal Capital Territory (FCT) in 2012, analyzed by the Minister of Trade and Investment, Mr. Olusegun Aganga at its inaugural presentation, showed that there were a total of 17.28 million SMEs in the country out of which 17.26 million are micro enterprises valued at less than NGN 5 million (This Day Newspaper, July 20, 2012). This represents about $99 \%$ of the MSMEs in Nigeria while Lagos State had the highest number of SMEs in the country with 17 per cent of the national figure, followed closely by Kano State, with Osun state having the fewest SMEs with only 0.4 per cent. Wastes from small scale industries and manufacturing companies producing polystyrene products, lead-acid batteries, dairy products, vehicle repair and maintenance workshops are all concentrated in urban centers and contribute in all form of solid wastes, leachates, effluents, and other emissions that pollute air, land, and water. Large-scale industries are established in large cities of Lagos, Ibadan, Port- Harcourt, Warri, Kano, and Kaduna. Other large scale industries are within the countryside but in close proximity to the city. They include cement and paper manufacturing companies. Other sources are gas flaring and oil and gas related activities etc. (Figure 1) [6].

\section{Nigeria's Geo-Climatic Profile}

- Nigeria covers an area of 923,768 sq km; about 1,200 km from east to west and about 1,050 km from north to south.

- The country is endowed with productive rivers and the ecology varies from tropical forest in the south to dry savanna in the far north, yielding a diverse mix of plant and animal life.

- Temperatures are high throughout the year, averaging from $25^{\circ} \mathrm{C}$ to $28^{\circ} \mathrm{C}$; in the higher elevations of the Jos Plateau, temperatures average $22^{\circ} \mathrm{C}$; Northern Nigeria experiences greater temperature extremes. Rainfall varies widely- parts of the coast along the Niger Delta, yearround, $>4,000 \mathrm{~mm} /$ year; in middle belt, during April/May through September/October and receives 1,000 to 1,500 $\mathrm{mm}$; in the dry savanna regions, rainfall is variable Nigeria's northeastern border receives $<500 \mathrm{~mm}$ per year, for less than three months.

- About two-thirds of Nigeria lies in the watershed of the Niger River (Africa's third longest river and fifth largest in terms of discharge), and its major tributaries, the Benue in the northeast, the Kaduna in the west, the Sokoto in the northwest, and the Anambra in the southeast. There are over 50 rivers exist.

- Nigeria's 77.7 per cent of land is cultivated (2013 statistics); soil fertility varies considerably but is generally poor; the most fertile of the soils are river valleys. Much of the land is overused and eroded; trees, which help prevent erosion, are often used for fuel, lumber, material for tools, fodder for animals, and herbal medicines.

- Urbanization in Nigeria is still low at 54.5\% (figures as of 2015). The largest cities, in order of size, are Lagos, Ibadan, and Kano. Other important cities include the Yoruba centers of Oyo, Ogbomosho, and Ife; the Hausa cities of Zaria, Katsina, and Sokoto; and the newer, colonial-era cities of Kaduna, Jos, and Enugu.

- Main industries in the country are: cement, oil refining, construction and construction materials, food processing and food products, beverages and tobacco, textiles, apparel and footwear, pharmaceutical products, wood products, pulp paper products, chemicals, ceramic products, plastic and rubber products, electrical and electronic products, base metals: iron and steel, information technology, automobiles, and others. Nigerian GDP is reported as USD 492.986 billion (2015).

- In 1988 Federal Government of Nigeria created the Federal Environmental Protection Agency (FEPA) to address problems of desertification, oil pollution, and land degradation, but the FEPA has had only a minor impact (Source: Institute for African Development (INADEV). 
Citation: Sridhar MKC, Coker AO, Achi C (2018) Pollution from Small and Medium Size Enterprises: Less Understood and Neglected Sources in Nigerian Environment. J Environ Anal Toxicol 8: 558. doi: 10.4172/2161-0525.1000558

The era of 1980s can be said to be golden years of SMEs in Nigeria. Those were the years of the Nigerian Industrial Development Bank Ltd (NIDB) and the Nigerian Bank for Commerce and Industry (NBCI). They were Federal Government Development Banks specifically dedicated to the development of SMEs in the country. The sector is responsible for about 70 per cent of the total industrial employment in Nigeria and between 10-15 per cent of the total manufacturing output. The agricultural sector which comprises mainly of SMEs have promoted indigenous technology and increased utilization of local raw materials [7]. Small and Medium Scale Industries Development Agency (SMEDAN) was established by an Act in 2003.

In 1996, manufacturing accounted for 8 per cent of the GDP, down from 13 per cent in 1982. Pre-independence Nigeria, its large population notwithstanding, had very little industrial development-a few tanneries and oil-crushing mills that processed raw materials for export. During the 1950s and 1960s a few factories, including the first textile mills and food processing plants, opened to serve Nigerians. During the 1970s and early 1980s industrial production increased rapidly, principally in Lagos, Kaduna, Kano, and Port Harcourt. Factories also appeared in smaller, peripheral cities such as Calabar, Bauchi, Katsina, Akure, and Jebba, due largely to government policies encouraging decentralization (although these policies sometimes ran counter to solid economic criteria).

In an attempt to broaden Nigeria's industrial base, the government has invested heavily in joint ventures with private companies. The largest such project is the integrated steel complex at Ajaokuta, built at a cost of USD 4 billion but still not operational after almost 20 years. The government has also invested heavily in petroleum refining, petrochemicals, fertilizers, and implements for assembling automobiles and farm equipment. The largest industrial sectors, in number of establishments, are food and beverages; textiles and clothing; wood and wood products; fabricated metal products and machinery; paper products; and chemical, petroleum, coal, rubber, and plastic products. The businesses in these sectors varied from large to small and labour-intensive such as weaving, leather making, pottery making, and woodcarving. The smaller industries are often organized in craft guilds involving particular families, who pass skills from generation to generation.

Major pollutants identified include: chemical wastes such as pesticides, petrochemicals, fertilizers, paints, textile, food beverages, and leather. Also suspended solids, grease and oil and more complex organic pollutants find their way to the urban waste stream entering waters in their localities. Leather and textile industries release various -dyes, tannin and chromium compounds which are particularly injurious to aquatic life [8-10].

The refineries generate different kinds of hazardous waste, such as combustion gases from flares and fuel burning gases (COx, NOx) leakages from valves, pump seals, flanges and water drained from storages tanks which contains volatile compounds and hydrocarbons and dissolved suspended matter. In many parts of Niger Delta Area there are illegal oil refineries and they pollute heavily even though they are small scale in operation. The most affected cities are Warri, Port Harcourt, Kaduna and other Riverine towns. Crude oil waste contains lead, and other dangerous metals. Some typical SMEs where majority of populations engage are shown in Figure 2.

Of the 50 urban areas with the worst ambient air pollution, four are in Nigeria. In Africa, unfortunately, the levels of pollution are increasing because of rapid economic development and industry without the right technology [5]. The survey also showed that only 3 per cent of the SMEs in Nigeria had access to the export market. The SMEs currently employ about 32.4 million people and makes about 46.54 per cent contribution to the GDP. The report also indicated that about 80 per cent of the SMEs are excluded from the financial market, and about 83.2 per cent have initial start-up capital of below NGN 10 million [11]. Selected examples of cities are given below with their SMEs, their activities and contribution to environmental pollution and pollution mitigation practices.

\section{Rivers state}

Port Harcourt is the capital of Rivers State, the administrative head of the oil rich Niger Delta of Nigeria and risen to the second largest seaport of Nigeria. Sequel to its strategic location, the city has witnessed tremendous growth in the commercial, industrial and other land-uses. Port Harcourt has an estimated population of 157,791,115. Most SMEs in Port Harcourt city operate as family/sole proprietorship business and are generally classified into commercial, industrial and agricultural categories depending on their activities though commercial SMEs constitute more than 90 percent of the entire number. There are 1,200 registered SMEs in Port-Harcourt city offering various products/ services to the general public. The activities of these SMEs were found to be welding, moulding, carpentry/furniture, milling/printing/graphic. These were concentrated in the areas-Rumuodomaya, Ogbunabali, Woji, Rumuokwurushi, Diobu and Rumueme.

The SMEs are grouped into various categories; Saw/Sand Dust 97 (39.5\%), Wood 34 (16.0\%), Paper 58 (29.0\%), Rubber 13 (6.5\%),

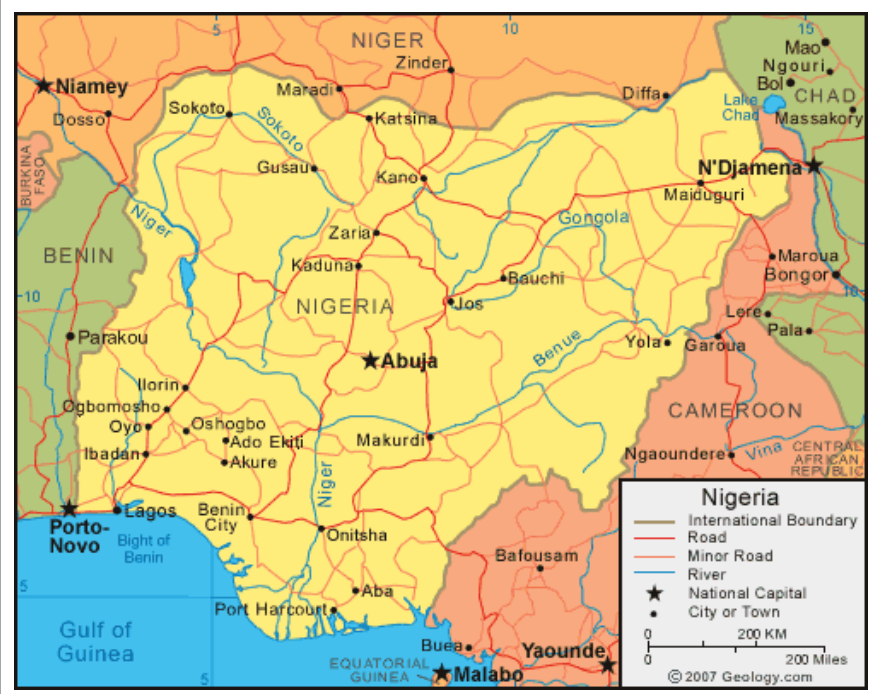

Figure 1: Map of Nigeria showing major cities. Source: Wikipedia 2016.

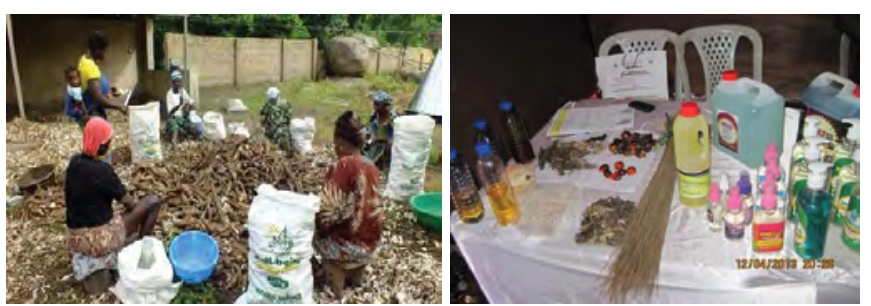

Figure 2: Typical SMEs and their products in Nigeria (Source: Authors collection). 
Citation: Sridhar MKC, Coker AO, Achi C (2018) Pollution from Small and Medium Size Enterprises: Less Understood and Neglected Sources in Nigerian Environment. J Environ Anal Toxicol 8: 558. doi: 10.4172/2161-0525.1000558

Page 4 of 7

Scrap Metal 6 (3.0\%), and Others 12 (6.0\%). The wastes contributed to air emissions were $33.0 \%$; solid waste $(27.5 \%)$; liquid waste $(8.5 \%)$; and noise $17.0 \%$. The methods of wastes disposal were: private open dump 14 (7.0\%), public open dump 11 (5.5\%), organized collection 58 (29.0\%), burning/burying $64(32.0 \%)$, inside the drain $12(6.0 \%)$ and recycling $41(20.5 \%)$. The results showed that the methods adopted were not environmentally friendly [12].

\section{Abia state}

Abia State is situated in the south eastern part of Nigeria. The capital is Umuahia and the major commercial city is Aba, formerly a British colonial government outpost. Crude oil and gas production is a prominent activity, as it contributes to $39 \%$ of the GDP. The manufacturing sector only accounts for $2 \%$ of the GDP. The industrial centre of the state is in Aba, popularly known as Japan of Africa 'with textile manufacturing, pharmaceuticals, soap, plastics, cement, footwear, and cosmetics. Representing $27 \%$ of the GDP, agriculture, which employs $70 \%$ of the state workforce, is the second economic sector of the State. With its adequate seasonal rainfall, Abia has much arable land that produces yams, maize, potatoes, rice, cashews, plantains, taro, and cassava. Oil palm is the most important cash crop.

According to a study [13] on the evaluation of solid waste management approaches in some industries in Aba, involving 192 respondents (from 25 SMEs), several findings were made. These were: respondents were waste managers, personnel and managers of industries: there were 8 SMEs $(20.00 \%)$ and the types were extracting 9 (22.50\%); hospitality 15 (37.50\%); manufacturing 4 (10.00\%); construction and processing industries $4(10.00 \%)$. The percentage volume of the waste generated by the companies is shown in Figure 3 .

\section{Kaduna state}

Kaduna State was created on May 27th 1967. It lies within the sub-humid agro-ecological zone of north central Nigeria. The state shares boundary with Zamfara, Katsina, Kano, in the North, Bauchi, Plateau in the East, while Nassarawa and Federal Capital Territory (FCT) in the South and Niger State in the West. The State is between longitudes $7^{\circ}$ and $9^{\circ}$ East of the Greenwich Meridian and also between latitudes $9^{\circ}$ and $11^{\circ}$ north of the equator. The State occupies an area of approximately $48,473.2$ square $\mathrm{km}$. Kaduna metropolis is the capital city of the State and occupies an area of about $260 \mathrm{~km}^{2}$, the distance between the eastern and western limits of the city is approximately $13.7 \mathrm{~km}$ [14]. It is made up of two main LGAs, the Kaduna North

\section{Volume}

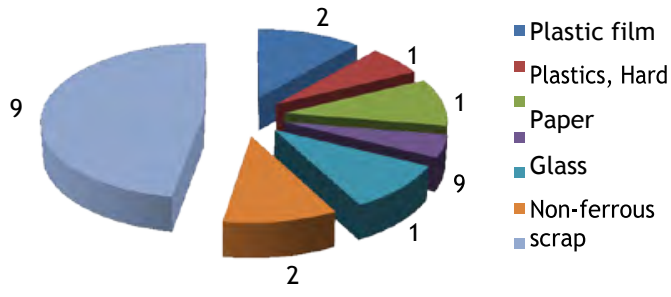

\section{$A=$ Wastesin}

Figure 3: Pie diagram showing various wastes in Aba. and the Kaduna South, other adjoining LGAs that make up the entire metropolis are Igabi and Chikun.

The rapid urbanization of the municipality has led to increased waste generation, which has overwhelmed the capacities of the Kaduna Environmental Protection Agency and Kaduna State Urban Development Authority. Decades ago, under Sardauna Ahmadu Bello priority was given to agriculturally based industries had vigorously commenced in 1955 , with a $£ 1,250,000$ investments that became Kaduna Textiles Limited. It domestically utilized the North's hitherto exported cotton in its 300 automatic looms that generated 1,617 jobs. More industries followed until the 1980s. At various points in time, not less than about 60 industrial firms operated in Kaduna State. These include breweries (e.g., IBBI and Nigerian Breweries Limited, NBL), textile firms (e.g., KTL, UNTL and Arewa Textiles), petrochemicals (e.g., Kaduna Refinery and Petrochemical Corporation, and Mennoil), and others such as Safa Foam, Kaduna Machine Works, BOC Gases, Fertilizer and Chemicals Ltd, NOCACO electrical products, Peugeot Automobile, and others. Some, like Peugeot, UNTL and NBL later commissioned effluent treatment plants.

Kaduna Environmental Protection Agency's (KEPA) records show that the ways in which these occur in Kaduna include the daily discharge of more than 20 million litres of industrial waste water which contains heavy metals, trace elements oxygen-depleting compounds and other elements, into the river. A study of industrial air pollution found that particulates emission from NNPC in Kaduna alone, reaches villages that are $60 \mathrm{~km}$ away. Other industries 'operations generate gaseous pollution in form of dense foul odour suspected to be the cause of cancer, bronchitis and other illnesses. Industrial sludge, spent oil grease and toxic solid wastes that are improperly disposed seriously contaminate the river and well water in Kakuri and Nassarawa area of Kaduna City. Yet drums used by textile, petrochemical and other firms to package these, easily find their way to domestic markets, for eventual use in storing water and food products.

The type of waste products, produced in Kaduna refining and petrochemical company are mainly solid waste. The liquid waste in the study area includes kerosene, diesel, fuel etc. Finally, the gas which is more than the other types of pollutants is formed as a result of industrial production and fuel combustion which produces smoke with carbonmonoxide, carbon dioxide, chlorofluorocarbons and hydrocarbons. It should be noted that all the above wastes produced by the industry are very disastrous and hazardous which affect human health, water bodies and the state of environment at large [15].

\section{Kano state}

Kano State has been a centre of industrial and commercial activities for centuries. The inhabitants of the city of Kano are known to have excelled in small scale industrial activities manifested in handicrafts, blacksmithing and agricultural activities. There are over 400 registered SMEs in Kano State but only about 108 are functioning [16]. Kano State is the second largest industrial centre in Nigeria and the largest in the Northern part of the country with textile, tanning, footwear, cosmetics and enamelware industries. Bally Plastics and footwear Ind. Nigeria Ltd, Royal Foam Production (NIG) Ltd, B. Galaxy Nigeria Ltd (germicide and insecticides), Jaykay carpet industries Ltd and Lakhi textiles are examples of some of the SMEs in Kano State. Like every other industrial area, Kano State is not an exception when it comes to industrial pollution. Since waste from pesticide industries is not properly disposed, the residents of these areas suffer from contaminated water and lands that are no longer fit for agricultural 
Citation: Sridhar MKC, Coker AO, Achi C (2018) Pollution from Small and Medium Size Enterprises: Less Understood and Neglected Sources in Nigerian Environment. J Environ Anal Toxicol 8: 558. doi: 10.4172/2161-0525.1000558

Page 5 of 7

production. Asthma, Birth defects, Neurological effects and hormone disruptions which are the few of many side effects faced by the people who live in the vicinity.

\section{Anambra state (Onitsha)}

Fuel and gas filling stations are the fastest growing industries in Anambra State. Most of these stations could be found along the highways and some on the major streets of Onitsha. Therefore, it is easier to identify these stations and their areas of influence where leakages in the underground tanks spill and pollutes the water, land and environment. There are over 106 functional stations in Onitsha town. Exhaust fumes from internal combustion engines also contribute to soil and water pollution due to the high number of vehicles on the roads [17]. Other known SMEs in Onitsha town are Giovanni marbles and granite limited, Igboamaka productions, Baba Mart Nigeria Ltd, Valchoid Oil and Gas ltd., Compilation filling station, Isigwe Uzoaga Petroleum Services Nigeria Ltd and many more.

Kristoral and Co. Limited is a plastic making industry situated in Onitsha North, Anambra. It manufactures both domestic and industrial plastics. It has done so much to add to the development of Anambra State and to the economy of the country, but like every other plastic manufacturing company, it has caused the residents of Onitsha its fair share of the plastic pollution. The lifestyle requires easily disposable products, such as soda cans, plastic bottles of water, but the accumulation of these products has led to increasing amount of plastic pollution in Nigeria. Plastics constitute major toxic pollutants and have caused great harm to the environment in the form of air, land and water pollution. Plastic waste from this plastic making industry affects plant life and makes lands unfit for farming and construction work [18].

\section{Oyo state}

Ibadan is the capital of Oyo State. The small scale industries located in a designated area were monitored. The site is the former Nigeria Tobacco Company premises and is named as Oyo State Small Scale Industries (OYSSIC). The premises and sheds are owned by the Government but leased to SMEs. A variety of products were being manufactured or repacked and the type of wastes generated is shown in Table 2.

\section{Nigerian Environmental Regulations}

Nigeria embraces the principle of sustainable development and this has found expression in the formulation of National Policy on the Environment, 1989. Several other Acts were formulated to address environmental problems and these are:

- Associated Gas Re-Injection Act CAP 26 of 1979;

- Factories Act CAP 126 was promulgated which provides for the registration of factories as well as relatively Free State from effluents arising from any drain, sanitary convenience or nuisance;

- The creation of Federal Environmental Protection Agency (FEPA) Act as amended by Decrees No. 59 of 1992 and No.14 of 1999 CAP 131 ;

- The National Environmental Protection (Effluent Limitation) Regulations S.I. 8 of 1991 which stipulates that every industry shall install anti pollution equipment for the detoxification of effluent and chemical discharges;

- National Environmental Protection (Pollution Abatement in Industries and facilities Generating Wastes); Regulations S.I. 9 of

\begin{tabular}{|c|c|c|c|c|c|c|}
\hline $\begin{array}{l}\text { Name of Company and } \\
\text { Hours of Operation }\end{array}$ & $\begin{array}{c}\text { Number } \\
\text { of } \\
\text { Workers }\end{array}$ & Products Manufactured & $\begin{array}{l}\text { Average Water } \\
\text { Consumption } \\
\text { per Day, litres }\end{array}$ & $\begin{array}{l}\text { Number } \\
\text { of Toilet } \\
\text { Units }\end{array}$ & $\begin{array}{l}\text { Solid Waste } \\
\text { Generated }\end{array}$ & $\begin{array}{c}\text { Mode of Solid Waste } \\
\text { Disposal }\end{array}$ \\
\hline 1.Unilever Nig. Plc; 9h & 22 & $\begin{array}{l}\text { Detergent powders: Omo, } \\
\text { Sunlight, Closeup toothpaste, Blue } \\
\text { band margarine, Lipton tea. }\end{array}$ & 440 & 2 & Used Cartons & Open dump. \\
\hline 2. Chi Limited; $9 \mathrm{~h}$ & 25 & $\begin{array}{c}\text { Fast moving consumer goods e.g., } \\
\text { Drinks }\end{array}$ & 500 & 4 & Packaging & Sorting and salvaging \\
\hline $\begin{array}{l}\text { 3. Prince and Princess Catering/ } \\
\text { Entertainment; } 6 \mathrm{~h}\end{array}$ & 6 & Entertainment & 120 & 3 & $\begin{array}{l}\text { Paper bottles, } \\
\text { plastics. }\end{array}$ & Open dump \\
\hline 4. The Lacasera Company Ltd.; $24 \mathrm{~h}$ & 30 & Beverage drinks & 600 & 2 & $\begin{array}{l}\text { Paper, wood, dust } \\
\text { from pallets. }\end{array}$ & $\begin{array}{l}\text { Landfill through } \\
\text { waste management } \\
\text { authorities. }\end{array}$ \\
\hline 5. Wealth lake Ind. Ltd.; 9h & 18 & Sachet water & 360 & 1 & Nylon & $\begin{array}{l}\text { Waste managemen } \mathrm{t} \text {, } \\
\text { landfill }\end{array}$ \\
\hline 6. Mayfold food concepts Itd.; $8 \mathrm{~h}$ & 25 & Dry chocolate food drink. & 500 & 4 & Paper, plastics, etc. & Open landfill \\
\hline 7. Jexcel commercial and security printers; $9 \mathrm{~h}$ & 15 & $\begin{array}{l}\text { General commercial printing on } \\
\text { paper. }\end{array}$ & 300 & 5 & Paper & Sorting and salvaging \\
\hline 8. Go-prompt Int. Ltd; 8h & 40 & $\begin{array}{l}\text { Manufacturing of corrugated } \\
\text { cartons from paper. }\end{array}$ & 800 & 3 & $\begin{array}{l}\text { Paper recycled for } \\
\text { use. }\end{array}$ & None \\
\hline 9. Power cool Nig. Ltd;9h & 12 & $\begin{array}{l}\text { Manufacturing of ice-block } \\
\text { machine. }\end{array}$ & 240 & 1 & Iron strap & $\begin{array}{l}\text { Sorting and } \\
\text { Salvaging. }\end{array}$ \\
\hline 10. Beautiful Interior Nig. Ltd; 8h & 8 & $\begin{array}{l}\text { Manufacturing of kitchen cabinets, } \\
\text { hardwood doors, wardrobes etc. }\end{array}$ & ND & - & Sawdust & $\begin{array}{l}\text { Landfill through } \\
\text { Contractor }\end{array}$ \\
\hline 11. Dansa Foods Ltd; 9h & 22 & Juice, water and dairy products & 440 & 2 & Paper, bottles. & Onsite incinerator. \\
\hline 12. MocDim Health and Fitness Centre; $10 \mathrm{~h}$ & 5 & $\begin{array}{l}\text { Herbal extract for health and } \\
\text { fitness services. }\end{array}$ & 100 & 2 & Bottles and papers & $\begin{array}{l}\text { Landfill/ Waste } \\
\text { Management } \\
\text { Authority. }\end{array}$ \\
\hline 13. Zans Foods and Beverages Ltd; 9h & 25 & Drinks. & 500 & 4 & papers & Incinerator \\
\hline 14. Intercontinental Distillers Ltd; 9h & 30 & $\begin{array}{l}\text { Sales and Marketing of } \\
\text { manufactured wines and spirits. }\end{array}$ & 600 & 2 & Papers and bottles & Landfill Open \\
\hline
\end{tabular}

Table 2: The SMEs in Oyo State Small Scale Industries complex in Ibadan and the various wastes generated (Data from the authors' field survey). 
Citation: Sridhar MKC, Coker AO, Achi C (2018) Pollution from Small and Medium Size Enterprises: Less Understood and Neglected Sources in Nigerian Environment. J Environ Anal Toxicol 8: 558. doi: 10.4172/2161-0525.1000558

Page 6 of 7

1991 stipulates that no industry shall release hazardous or toxic substance into the air, water or land of Nigerians ecosystem beyond limits approved by the Agency. It maintains that a discharge (Solid, gaseous and liquid waste) from any industry or facility shall be analyzed and reported every month, to the nearest office of the agency.

- Subsequently, the Environmental Guidelines and standards for the petroleum Industry 1991 were established to regulate activities of all oil or petroleum industries.

- To further address environmental issues in Nigeria Environmental Impact Assessment (EIA) Decree. 86, was enacted; it stipulates that: - where the extent, nature or location of a proposed project or activity is such that is likely to significantly affect the environment, it environmental impact assessment shall be undertaken in accordance with the provisions of the Decree.

- To further buttress the environmental problems and to enhance quality of the environment, oil and Gas Pipelines Regulations S.I. 14, 1995 was formulated to provide pipeline design, standard of design, construction, inspection and testing, environmental protection guideline operation and maintenance guidelines. The National Guidelines on Registration of Environmental friendly Products and Eco-labeling CAP 1999 encourages business to produce goods, which are environmentally friendly, both as contribution to protecting the environment and to providing competitive advantage for Nigeria's product in the global market. It also encourages industries to market environmentally friendly certified products.
- Another one is the National Guidelines on Environmental Management system in Nigeria CAP. 1999 which calls for an Environmental Management System (EMS) to provide order and consistency for organization to address environmental concerns through the allocation of resources, assignment of responsibilities and continuous evaluation of practices, procedures and processes. The basic objectives are to: achieve its environmental policy, objectives and targets, including compliance with environmental legislation, identify and control the environmental aspect, impacts and risks relevant to the organization. The core elements include; environmental policy, initial Environmental Review as well as Environmental Action Plan.

\section{Pollution Control Devices used by the SMEs}

In general, the regulatory bodies ignore or play low on the pollution control issues from SMEs. Rather they focus on large scale industries such as breweries, confectioneries and food and beverage based, etc. There is no data base for such industries. The solid wastes are collected, heaped and contracted out to private waste handlers who register with the State Ministry of Environment. They have a fixed fee for the amount and type of waste being cleared on a regular basis. Some industries heap them up and burn at intervals.

Some of the technologies used for managing liquid wastes were septic tank system, trickling filter, aerated lagoon, oxidation ditch, simple ponding or letting into streams and open land untreated [19]. By these methods, the problem is not addressed but the waste is moved out of sight. In 2001, the Federal Ministry of Environment inaugurated different consultants to carry out a study for the construction of

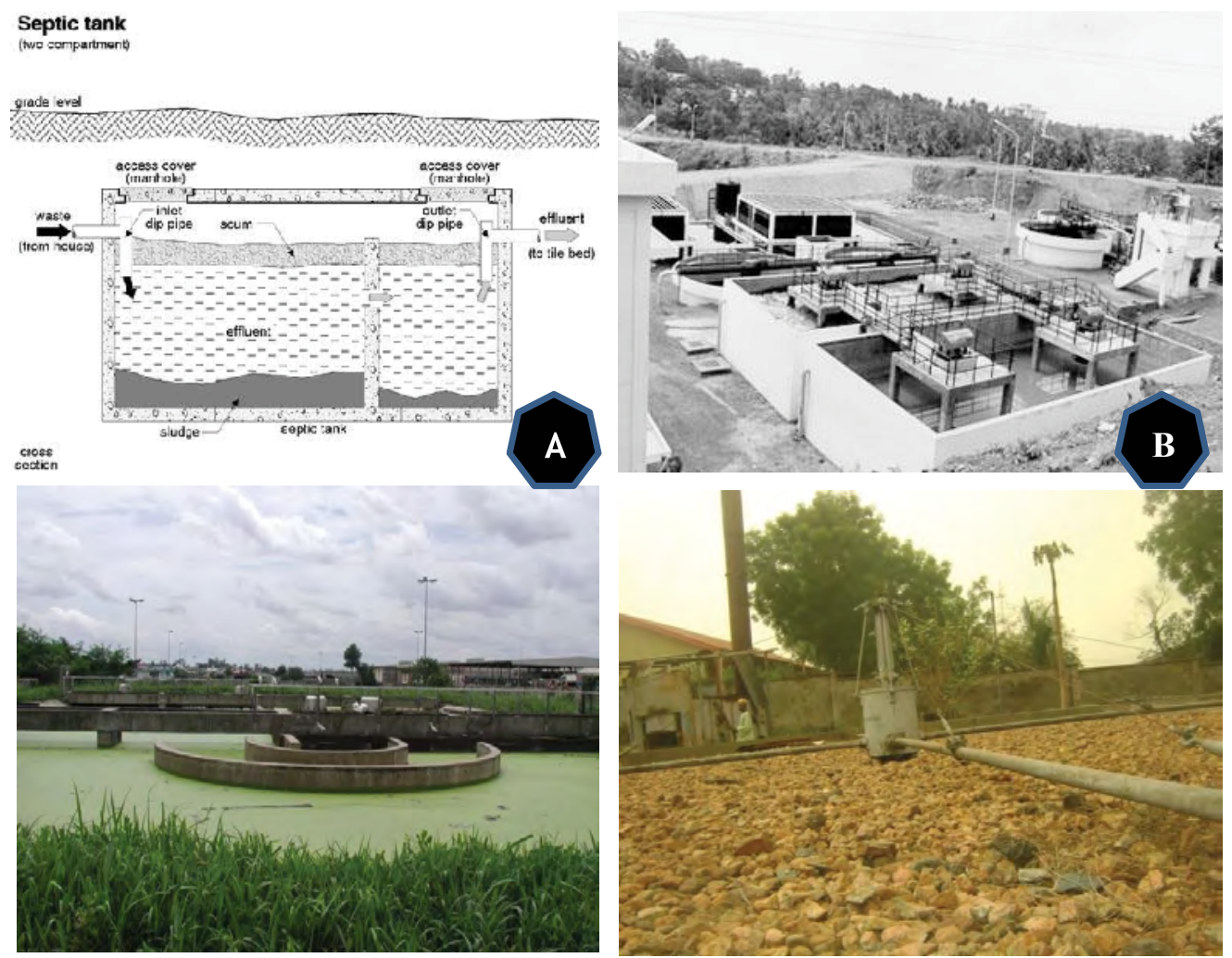

Figure 4: The common effluent treatment facilities. A=A Septic tank system; B=WEMABOD Treatment Plant in Lagos; C=An Oxidation Ditch in Lagos at a Pig farm; $\mathrm{D}=\mathrm{A}$ Trickling Filter system at NTC, Ibadan (Source: Authors collection). 
Citation: Sridhar MKC, Coker AO, Achi C (2018) Pollution from Small and Medium Size Enterprises: Less Understood and Neglected Sources in Nigerian Environment. J Environ Anal Toxicol 8: 558. doi: 10.4172/2161-0525.1000558

industrial ETPs in Lagos, Aba, Kaduna and Kano. They, however, did not take off. However, some aborted attempts were made in Lagos, Ibadan and a few other industrial townships (Figure 4).

\section{WEMABOD, Ikeja, Lagos}

WEMABOD Estates Limited, the Ikeja Industrial Estate is home to many manufacturing companies, including Guinness Plc, Dunlop Plc, Cocoa Industries Limited, Reliance Textile Mills, Neimeth Plc, Nigerite Plc, WAMCO Freisland and a host of others. Initially, an Effluent Treatment Plant (ETP) was built for the estate in 1965 with the capacity to process 19,000 cubic metres of industrial wastes daily, and could only take care of biological waste stream. This plant had failed due to improper management and letting in toxic effluents without any pretreatment [20].

\section{Ibadan}

In Ibadan, an attempt was made to build a hazardous waste leachate pit and a hazardous waste dump site to treat wastes from Exide battery industry. This project was commissioned but was never used as the battery industry was closed down. Yet in another instance, the Nigeria Tobacco Company (NTC) built an Effluent Treatment Plant (ETP) to treat their effluent. However, due to expansion, the plant could not operate and was abandoned. The Oyo State Small Scale Industries took over the site and the ETP with the hope the SMEs will use it. But unfortunately, the SMEs which took over were dry industries and no liquid wastes were produced. The ETP remained unused. A septic tank is used for liquid wastes that are generated (Figure 4).

\section{Challenges}

Small and Medium Size Enterprises are drivers of economic growth in a developing country like Nigeria. Given a policy support, they can replace the primary sources of income in national economy. These industries are simple to own, operate and manage with minimal support from any financial institutions. Some of these are service based. Entrepreneurship in waste recycling is another area where many unskilled operators find solace in making adequate financial gains [21]. The main types are agro-based, livestock based, non-agricultural, mineral based, and skills based which require minimal training. There are less bureaucratic procedures and intensive infrastructural needs. The SMEs in Nigeria are faced with several preventable or avoidable challenges. The major challenges include: high energy cost, weak consumer demand, policy inconsistency, multiplicity of taxes and levies, institutional bottlenecks, high cost of funds and poor state of infrastructure. A glaring lapse on the management of the SMEs in Nigeria are lack of environmental conscience among the entrepreneurs and also lukewarm attitude of the State Ministries and regulatory bodies. As a result, the areas where these SMEs are demarcated suffer from environmental degradation, water pollution, soil pollution and polluted air. These environmental concerns may lead to greenhouse gas emissions and a threat to climate. There is need for the government and the regulatory bodies to evolve simple mitigation measures to reduce the pollutant discharges and create awareness among the SME owners and operators [22-25].

\section{References}

1. Onibokun A, Faniran A (2013) Urban Research in Nigeria. Chapter 2. Institut français de recherche en Afrique. Multi-formats, pp: 5-17.
2. Eneh OC, Agbazue VC (2011) Protection of Nigeria's environment: A critica policy review. Journal of Environmental Science and Technology 4: 490-497.

3. Agwu MO, Emeti $\mathrm{Cl}$ (2014) Issues, challenges and prospects of small and medium scale enterprises (SMEs) in Port-Harcourt City, Nigeria. European Journal of Sustainable Development 3: 101.

4. Basil ANO (2005) Small and Medium Enterprises (SMES) in Nigeria: Problems and Prospects. PhD Thesis. St. Clement's University.

5. Orijoadmin O (2016) Four of the world's polluted cities are in Nigeria. WHO.

6. Obi J, Okekeogbu CJ (2011) Journal of Environmental Management and Safety 2: 25-41.

7. Cassavamillers (2016) An overview of small and medium enterprises (SMEs) in Nigeria. Available from: www.cassavamillers.com Accessed on June 18, 2016.

8. World Bank (1995) Nigerian Strategic Option for Readdressing Industrial Pollution. Industry and Energy Division. West Central Africa Department, February World Bank, Washington DC, USA.

9. World Bank (1995) Restoring Urban Nigeria: A strategy for restoring urban infrastructure and service in Nigeria. Prepared by the World Bank with Nigeria Collaboration. World Bank, Washington DC, USA.

10. World Bank (1995) Defining an environmental department strategy For the Niger Delta. I \& II. Report prepared by Smith J, Moffat D, Linden O. Industry and Energy Operations Division, West Central African Department, World Bank, Washington DC, USA.

11. Adebisi A, Sunday GC, Ofuani AB (2015) Challenges of finance and the performance of small and medium enterprises (SMEs) in Lagos State. Developing Country Studies 5: 46-57.

12. Baadom LE, Aselemi EA, Ayagere SA, Tobi DS (2016) Environmental Impact of Small Scale Industries on the Urban Environment of Port Harcourt. International Journal of Sustainable Development 11: 11-24.

13. Ajero CM, Chigbo UN (2012) A study on the evaluation of industrial solid waste management approaches in some industries in Aba, South Eastern Nigeria. West African Journal of Industrial and Academic Research 4: 103-112.

14. Fingesi ET (2001) The Effect of Sectarian Riots on Housing Supply in Barnawa

15. Rowland AJ, Cooper P (1983) Environment \& Health. Published by Edward Arnold, London, UK.

16. Ado-Kurawa I (2006) Investment opportunities in Kano: the centre of commerce Research and documentation directorate, Kano state government Kano state economic empowerment and development strategy (K-SEED).

17. Ogbuagu A (1998) Industrial pollution survey in Anambr. Journal of Environmental Contamination and Toxicology 9: 269-275.

18. Ezeabasili AC, Anike OL, Okoro BU (2015) Urban water pollution by heavy metals and health implication in Onitsha, Nigeria. African Journal of Environmental Science and Technology 9: 325-331.

19. Banjoko B, Sridhar MKC (2015) Upgrading Wastewater Treatment Systems for Urban Water Reuse. In: Urban Water Reuse Handbook. John Wiley Inc., London, pp: 461-480.

20. Dada A (2007) Industrial estate to get $\$ 40 \mathrm{~m}$ effluent plant, Punch, Nigeria.

21. Sridhar M, Taiwo HB, Okoye A (2016) Entrepreneurship in waste recycling Bookbuilders edn. Africa, Ibadan, A Publication from SRH Ecosolutions Ltd. Ibadan, Nigeria, pp: 1-681.

22. Panisello PJ, Quantick PC (2001) Technical barriers to hazard analysis critical control point (HACCP). Food Control 12: 165-173.

23. Obi NI, Okekeogbu CJ (2011) Waste Management for Sustainable Environment A Way Forward for Nigeria. Journal of Environmental Management and Safety 2: 25-41.

24. Ogechukwu AD, Oboreh JS (2013) Small and medium scale enterprise (SMEs) in Nigeria the marketing interface. Global Journal of Management and Business Research.

25. Wikipedia (2016) List of cities in Nigeria. Accessed June 12, 2016. 